\title{
Loris Petris, Vestiges de la bibliothèque du Cardinal Jean Du Bellay
}

\section{Filippo Fassina}

\section{Q OpenEdition}

1 Journals

\section{Edizione digitale}

URL: http://journals.openedition.org/studifrancesi/9464

DOI: $10.4000 /$ studifrancesi.9464

ISSN: 2421-5856

\section{Editore}

Rosenberg \& Sellier

\section{Edizione cartacea}

Data di pubblicazione: 1 décembre 2007

Paginazione: 639

ISSN: 0039-2944

\section{Notizia bibliografica digitale}

Filippo Fassina, «Loris Petris, Vestiges de la bibliothèque du Cardinal Jean Du Bellay», Studi Francesi

[Online], 153 (LI | III) | 2007, online dal 30 novembre 2015, consultato il 08 janvier 2021. URL: http:// journals.openedition.org/studifrancesi/9464; DOI: https://doi.org/10.4000/studifrancesi.9464

Questo documento è stato generato automaticamente il 8 janvier 2021.

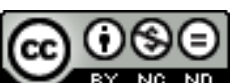

Studi Francesi è distribuita con Licenza Creative Commons Attribuzione - Non commerciale - Non opere derivate 4.0 Internazionale. 


\title{
Loris Petris, Vestiges de la bibliothèque du Cardinal Jean Du Bellay
}

\author{
Filippo Fassina
}

\section{NOTIZIA}

LORIS PETRIS, Vestiges de la bibliothèque du Cardinal Jean Du Bellay, «Bibliothèque

d'Humanisme et Renaissance», LXIX, 1 (2007), pp. 131-145.

1 Il presente studio consiste in una rassegna completa e dettagliata dei testi presenti nella biblioteca personale del cardinale Jean Du Bellay. L'A. sottolinea, in particolare, il forte interesse dello studioso per le opere degli umanisti italiani, ma anche per discipline meno consuete, come l'orticoltura. Tra gli altri ambiti, spiccano i testi relativi alla Germania protestante e alla retorica (in particolar modo l'oratoria ciceroniana), mentre non mancano testi puramente letterari, soprattutto di poesia. La quantità e la varietà di testi (peraltro elencati in appendice) dimostrano la grande erudizione di Du Bellay e offrono un ritratto ricco e completo di una delle figure più importanti $e$ influenti dell'epoca. 